\title{
Partial end organ resistance to thyroid hormone in congenital hypothyroidism
}

\author{
JOHN M. C. CONNELL* \\ M.B., M.R.C.P. \\ E. H. MCLaren $\dagger$ \\ B.Sc., F.R.C.P. \\ Departments of Medicine, *Western Infirmary, Glasgow G11 GNT, and †Stobhill General Hospital, \\ Glasgow G21 3UW
}

\begin{abstract}
Summary
End organ resistance to thyroid hormone has been described for a number of years: the defect may be partial or generalized. A case of partial end organ resistance to thyroid hormone in congenital hypothyroidism is described, with evidence of an alteration in TSH threshold to feedback inhibition by thyroid hormone. The implications of this factor in the management of hypothyroidism are discussed.
\end{abstract}

\section{Introduction}

A number of cases of end organ resistance to the action of thyroid hormone has been reported over the past few years (Bode, Danon and Weintrub, 1973; Elewant, Mussche and Vermenten, 1976). In some cases the defect appears to lie only at pituitary level, with inappropriately elevated levels of thyroid stimulating hormone for thyroid hormone levels at or above the upper end of the normal range, and clinical features of thyrotoxicosis (Gershengorn and Weintrub, 1975). Other cases have been described with a more generalized end organ resistance, with clinical features including deaf mutism, goitre and stippled bony epiphyses (Refetoff, De Wind and De Groot, 1967). Recent evidence suggests that in some cases there is reduced affinity of nuclear receptors for $T_{3}$ (Daubresse et al., 1980). These previously reported cases with normal thyroid gland function, however, responded to chronically elevated thyroid-stimulating hormone (TSH) concentrations with goitre formation. Reports have also been made of an elevation in the threshold for TSH suppression by thyroid hormone in congenital hypothyroidism, which may be regarded as a partial end organ resistance phenomenon (Schultz, Glassman and MacGillivray, 1980; Sato et al., 1977). The authors describe a case of pituitary end organ resistance to thyroid hormone in a child with congenital hypothyroidism which, they believe, differs from previously reported cases.

\section{Case report}

A female infant was born in September 1970 and congenital agoitrous hypothyroidism was diagnosed on clinical and biochemical grounds shortly after birth (serum $\mathrm{PBI}<1.8 \mu \mathrm{g} / \mathrm{dl}$ ). She was started on L-thyroxine $0.03 \mathrm{mg}$ daily. Initial progress was satisfactory. In July 1971 , on $0.04 \mathrm{mg}$ thyroxine daily, her bone age was normal, and no developmental $\infty$ delay was detected. Over the next few years her $\subseteq$ clinical progress was satisfactory, and the dose of thyroxine was gradually increased to $0.1 \mathrm{mg}$ daily. In August 1978, while on that dose, total $T_{4}$ was $242 \mathrm{nmol} / 1$, and $\mathrm{T}_{3}$ was $2.9 \mathrm{nmol} / \mathrm{l}$ (Table 1). She $\stackrel{9}{+}$ was clinically euthyroid and the growth velocity was $\overrightarrow{0}$ normal. Bone age, however, was retarded at 6 years $\infty$ Because of the biochemical evidence of over-replace ment, the dose of thyroxine was reduced to 0.07 ? $\mathrm{mg} /$ day.

At review one year later, she was thought to be clinically euthyroid. Intellectual development was normal, and growth velocity had been maintained, with height and weight above 25th and below 40th centiles. $T_{4}$ at that time was again elevated at $161 \mathrm{nmol} / 1$, with a high $T_{3}$ at $3.1 \mathrm{nmol} / \mathrm{l}$; TSH was also elevated at $>60 \mathrm{mu}$./1. Because of the discrepancy between non-suppression of thyroid stimulating hormone despite the clearly adequate levels of $T_{4}$ and $T_{3}$, she was admitted to hospital for supervision of therapy.

During admission, she was maintained on $0.075 \mathrm{mg}$ of thyroxine daily. $T_{4}$ and $T_{3}$ levels were consistently at the upper end of the normal range, and elevated TSH levels were confirmed (Table 1). Free $T_{4}$ and $\frac{D}{2}$ thyroid-binding globulin were within the normal range. A thyrotrophin-releasing hormone (TRH) o test was compatible with 'hypothyroidism', showing N an exaggerated increment following the i.v. injection of $200 \mu \mathrm{g}$ of TRH. Serum cholesterol was normal. In an effort to gauge the tissue response to circulating thyroid hormone, left ventricular contractility was assessed by measuring systolic time intervals, $\overparen{D}$ using the method described by Parisi et al. (1974). This suggested that the child was euthyroid. The pituitary fossa was normal radiologically and no goitre was palpable. 
The thyroxine dose was then increased to $0 \cdot 1$ $\mathrm{mg} /$ day and thyroid function tests were repeated after several weeks as an out-patient. Total $T_{4}$ and $T_{3}$ levels were now clearly outside the normal range, and free $T_{4}$ was also elevated (Table 1). TSH was, however, now suppressed at $2 \cdot 6 \mathrm{mu}$./1. Clinical assessment at this time was consistent with marginal over-replacement of thyroxine, and systolic time intervali were also consistent with this finding. In view of the retarded bone age, however, the dose of thyroxine was maintained at $0.1 \mathrm{mg} / \mathrm{day}$. At the latest review she was well, and clinical progress was thought to be satisfactory. Persistent elevation of total $T_{4}$ and $T_{3}$ was confirmed, as was suppression of TSH to within the normal range. Regular review of this dose will be carried out and skeletal, intellectual and motor development closely monitored.

\section{Discussion}

This case is thought to be unusual: the finding of chronically elevated TSH levels with clinical, biochemical, metabolic and physiological evidence of euthyroidism, and suppression of TSH secretion only when free $T_{4}$ rose into the 'thyrotoxic' range, with associated clinical and physiological evidence of thyroid over-replacement is, the authors think, evidence of an alteration in end-organ sensitivity to thyroid hormone negative feedback effects at hypothalamic/pituitary level.

Correlation between free $T_{4}$ levels and systolic time intervals suggests that myocardial end organ response to thyroid hormone is normal: it is possible that the persistently retarded bone age is evidence of an end organ defect affecting other tissues.

Previous reports of an elevation in the threshold for TSH suppression in congenital hypothyroidism have described similar observations to the present ones, with elevation in TSH levels despite 'adequate' thyroxine replacement doses judged by clinical criteria (Schultz et al., 1980; Sato et al., 1977). Schultz et al. (1980) postulated that this phenomenon may be a consequence of failure of development of sufficient numbers of receptors for thyroid hormone in the fetal hypothalamic/pituitary regulatory centres, owing to sub-normal fetal concentrations of the hormone. Thus, in both of the previous reports, the abnormalities in TSH suppressibility were noted at the initiation of therapy; the total duration of therapy observed was not more than 24 months in any case. It was postulated that the threshold for thyrotropin suppression is initially high, but that the pituitary/hypothalamic centres become increasingly sensitive to thyroid hormone negative feedback effects with prolonged therapy. Thus higher doses of thyroxine replacement therapy may be necessary to suppress TSH in infancy than in later childhood (Sato et al., 1977).

In the present case, however, the abnormality in TSH suppressibility was only detected after 8 years of thyroxine therapy, in doses which were clinically and biochemically (in terms of PBI and total $T_{4}$ ) adequate. This does not accord with the hypothesis of Sato et al. stated above, and suggests that, in some children at least, the elevated threshold for TSH suppression may be a more prolonged, or even a permanent feature.

In current management of children with hypothyroidism, attainment of $T_{3}$ and $T_{4}$ levels in the 'normal' range, and the suppression of an elevated TSH level are taken as guides to the adequacy of therapy (Rezvani and Di George, 1977). The authors would, however, extend the caveat expressed

TABLE 1.

\begin{tabular}{|c|c|c|c|c|c|c|}
\hline Date & $\begin{array}{c}\text { Daily } \\
\text { thyroxine } \\
\text { replacement } \\
\text { dose }\end{array}$ & $\underset{\text { (nmol/l) }}{\text { Total }_{4}}$ & $\underset{\text { (nmm }}{\left.T_{3} l / 1\right)}$ & $\underset{\text { (mu./l) }}{\text { TSH }}$ & $\begin{array}{c}\text { Free } \\
T_{4} \\
(\mathrm{pmol} / \mathrm{l})\end{array}$ & $\begin{array}{c}\text { Thyroid } \\
\text { binding } \\
\text { globulin } \\
\text { (mg/l) }\end{array}$ \\
\hline $\begin{array}{c}1978 \\
\text { February }\end{array}$ & 0.1 & 179 & $4 \cdot 1$ & $2 \cdot 4$ & & \\
\hline $\begin{array}{c}1979 \\
\text { August } \\
\text { August } \\
\text { October } \\
\text { October }\end{array}$ & $\begin{array}{l}0.1 \\
0.075 \\
0.075 \\
0.075\end{array}$ & $\begin{array}{l}242 \\
161 \\
139 \\
144\end{array}$ & $\begin{array}{l}2 \cdot 9 \\
3 \cdot 1 \\
2 \cdot 8 \\
2 \cdot 3\end{array}$ & $\begin{array}{l}60 \\
32 \cdot 8 \\
33 \cdot 6^{*} \\
50^{*} \\
50^{*}\end{array}$ & 25 & 29 \\
\hline $\begin{array}{c}1980 \\
\text { February } \\
\text { June }\end{array}$ & $\begin{array}{l}0.1 \\
0.1\end{array}$ & $\begin{array}{l}214 \\
157\end{array}$ & $\begin{array}{l}3 \cdot 3 \\
3 \cdot 2\end{array}$ & $\begin{array}{l}2 \cdot 6 \\
2 \cdot 2\end{array}$ & 43 & 38 \\
\hline
\end{tabular}

*TRH test: $200 \mu \mathrm{g}$ (TRH given i.v.); TSH concentrations at 0,20 and $60 \mathrm{~min}$.

Normal values: $\mathrm{T}_{4}=55-144 \mathrm{nmol} / 1 ; \mathrm{T}_{3}=0 \cdot 9-2 \cdot 8 \mathrm{nmol} / 1 ; \mathrm{TSH}=<8 \mathrm{mu} . / 1 ;$ Free $_{4}=10-30 \mathrm{pmol} / 1$; Thyroid binding globulin $=$ $12-30 \mathrm{mg} / \mathrm{l}$.

$T_{4}, T_{3}$ and TSH measured by radioimmunoassay using a double antibody method. Free $T_{4}$ and thyroid binding globulin measured using a Corning medical systems assay kit. 
by Schultz et al. that alteration of the dose of thyroid hormone to attain TSH suppression places the infant at risk for overtreatment' to embrace all children (and perhaps even adults) with congenital hypothyroidism. Clearly, where there is a change in the relationship between peripheral levels of thyroid hormone and TSH secretion, the concept of 'euthyroidism' becomes harder to define, and repeated careful clinical assessment of the patient is of paramount importance in the control of therapy. Other indices of peripheral thyroid hormone status, such as the systolic time-interval measurement and serum cholesterol, can provide useful, reproducible ancillary aids to management.

\section{Acknowledgment}

We would like to acknowledge the help of Dr Stuart Hillis in measuring and interpreting systolic time intervals.

\section{References}

Bode, H.H., Danon, M. \& Weintrub, B.D. (1973) Partial target resistance to thyroid hormone. Journal of Clinical Investigation, 52, 776.

Daubresse, J.C., Dozin-Van Roye, B., De Nayer, P. \& De VISSCHER, M. (1980) Partial resistance to thyroid hormones: reduced affinity of lymphocyte nuclear receptors for in two siblings. (Abstract) VIIIth International Thyraid Congress, The Australian Academy of Science, 1980.

Elewant, A., Mussche, M. \& Vermenten, A. (19) Familial partial target organ resistance to thyroid hormores. Journal of Clinical Endocrinology and Metabolism, 43, 85 . Gershengorn, M.C. \& Weintrub, G.D. (1975) Thyrotrop fin induced hyperthyroidism caused by selective pituit स्सु:y resistance to thyroid hormone. Journal of Clinical Inve gation, 56, 633.

Parisi, A.F., Hamilton, B.P., Thomas, C.N. \& Mazzaferigi, E.L. (1974) The short cardiac pre-ejection period: an in\&ex to thyrotoxicosis. Circulation, 48, 900.

Refetoff, S., De Wind, L.T. \& De Groot, L.J. (1967) Familial syndrome combining deaf mutism, stippted epiphyses, goiter and abnormally high PBI: possify target organ refractoriness to thyroid hormone. Joureal of Clinical Endocrinology and Metabolism, 27, 279.

Rezvani, I. \& Di George, A.M. (1977) Reassessment of daily dose of oral thyroxine for replacement therapy hypothyroid children. Journal of Pediatrics, 90, 291.

Sato, T., Suzuki, Y., Taketani, T., Ishiguro, K. $\overbrace{\&}$ Nakajima, H. (1977) Age-related change in pituitarly threshold for TSH release during thyroxine replacement therapy for cretinism. Journal of Clinical Endocrinologe, 44, 553.

욱.

Schultz, R.M., Glassman, M.S. \& MacGillivray, M.H. (1980) Flevated threshold for thyrotropin suppression in congenital hypothyroidism. American Journal of Diseases of Children, 134, 19. 